\title{
Distribution and Taxonomy of Shallow Marine Ostracods from the Western Coast of the Red Sea, Egypt
}

\author{
Ebtesam A. Yousef \\ Zoology Department, Faculty of Science, Sohag University, Sohag, Egypt \\ Email: a_ebtesam@yahoo.com
}

How to cite this paper: Yousef, E.A. (2018) Distribution and Taxonomy of Shallow Marine Ostracods from the Western Coast of the Red Sea, Egypt. Open Journal of Marine Science, 8, 51-75.

https://doi.org/10.4236/ojms.2018.81004

Received: December 6, 2017

Accepted: January 19, 2018

Published: January 22, 2018

Copyright $\odot 2018$ by author and Scientific Research Publishing Inc. This work is licensed under the Creative Commons Attribution International License (CC BY 4.0).

http://creativecommons.org/licenses/by/4.0/

\section{(c) (i) Open Access}

\begin{abstract}
A total 5849 individuals of ostracods constituting twenty species were collected from five shallow marine sites along the area from El-Quseir to Marsa Alam on the West Coast of the Red Sea. The twenty ostracod species belonging to sixteen genera and ten different families. The three genera; Loxoconcha, Neonesidea and Xestoleberis have high species diversity. Furthermore, the species Loxoconcha ghardaqensis, Xestoleberis rotunda, Paranesidea fracticorallicola, Tanella gracilis and Neonesidea schulzi were the best recognized in the collecting region. Otherwise, the distribution of the collected ostracod species in relation to environmental variables and plants were discussed in detail here. Based on this, it is concluded that, vegetation type appears to be the most important factor controlling the distribution of ostracod species in the investigated area. Also, other factors such as, water temperature, salinity, dissolved oxygen, $\mathrm{pH}$ and electrical conductivity play an important role. Scanning electron microscope images of valves are delivered of the recorded taxa. These fauna displays close affinities to those of the Red Sea and the Indo-Pacific region.
\end{abstract}

\section{Keywords}

Marine Ostracods, Taxonomy, Distribution, Ecology, Red Sea

\section{Introduction}

Ostracoda are a class of small crustaceans distinguished by a carapace of two valves enveloping soft parts and appendages. The dorsal margin of the two valves is joined by hingement. Ostracods are inhabiting in all watery environments (marine, brackish, freshwater and terrestrial) and they are playing vital 
role in aquatic ecosystems. Besides, they are affected by the variations of ecological characters such as: salinity, water temperature, $\mathrm{pH}$, dissolved oxygen, electrical conductivity and total dissolved salts (TDS).

Ostracods of the Egyptian Red Sea Coast are abundant and diverse, until now little investigations carried out on the taxonomy of ostracods in the Red Sea. [1] studied the taxonomy of some ostracod species on Hurghada and Bonaduce et al. [2] and Bonaduce et al. [3] recorded some ostracod species from the Gulf of Aqaba (Red Sea). Also, [4] and [5] investigated ostracods in the Safaga Bay and in mangrove ecosystems, respectively.

The current study focused on the taxonomy of shallow ostracods for the first time in the region from Al-Quseir to Marsa Alam along the west Coast of the Red Sea. The objective of the present study is to evaluate the distribution and study the taxonomy of shallow ostracod species in the collection area. In order to recognize the diversity of these taxa and to conclude the appropriate ecological conditions in which they grow and thrive.

\section{Materials and Methods}

Shallow samples were collected in June, 2016 by nylon net (mesh size $150 \mu \mathrm{m}$ ) from five sites on the West Coast of the Red Sea extends from Al-Quseir to Marsa Alam (Figure 1). These sites (Table 1) are termed from north to south; (I) North Wadi Syatin, (II) North Wadi Asal contains mangrove trees, (III) South Wadi Um Gerifat, (IV) South Wadi Abu Dabbab and (V) South Wadi Abu Ghusun. Additionally, the sites I and III are covered by macro-algae, while the mangrove trees occurrence in sites II, IV, V. These sites selected to know, if ostracod species preferred to live between macro-algae or between mangrove trees.

Ecological variables such as $\mathrm{pH}$, dissolved oxygen $(\mathrm{mg} / \mathrm{L})$, water temperature (C), electrical conductivity [l S/cm], total dissolved salts (TDS) and salinity (ppt) were measured using an environmental Multi Probe System.

In the laboratory, ostracod species were separated, picked, counted and then preserved in an alcohol (70\% concentration). For scanning electron microscope studies, ostracod species were fixed in a mixture of three volumes of $4 \%$ glutraldehyde and one volume of $1 \%$ of osmium tetraoxide. Then they were dehydrated in an ordered series of ethanol and sputter-coated with gold, and viewed under a JSM $5400 \mathrm{LV}$ SEM, at an accelerating voltage of $15 \mathrm{kV}$ at Assiut University.

Table 1. Sampling stations and geographical position.

\begin{tabular}{ccc}
\hline Sites & Latitude & Longitude \\
\hline North Wadi Syatin(I) & $26^{\circ} 9^{\prime} 51.85^{\prime \prime} \mathrm{N}$ & $34^{\circ} 14^{\prime} 37.96^{\prime \prime} \mathrm{E}$ \\
North Wadi Asal (II) & $26^{\circ} 2^{\prime} 51.62^{\prime \prime} \mathrm{N}$ & $34^{\circ} 18^{\prime} 58.97^{\prime \prime} \mathrm{E}$ \\
South Wadi Um Gerifat (III) & $25^{\circ} 39^{\prime} 6.64^{\prime \prime} \mathrm{N}$ & $34^{\circ} 34^{\prime} 49.84^{\prime \prime} \mathrm{E}$ \\
South Wadi Abu Dabbab (IV) & $24^{\circ} 42^{\prime} 38.30^{\prime \prime} \mathrm{N}$ & $35^{\circ} 55^{\prime} 30.92^{\prime \prime} \mathrm{E}$ \\
South Wadi Abu Ghusun(V) & $24^{\circ} 27^{\prime} 3.05^{\prime \prime} \mathrm{N}$ & $35^{\circ} 12^{\prime} 15.45^{\prime \prime} \mathrm{E}$
\end{tabular}




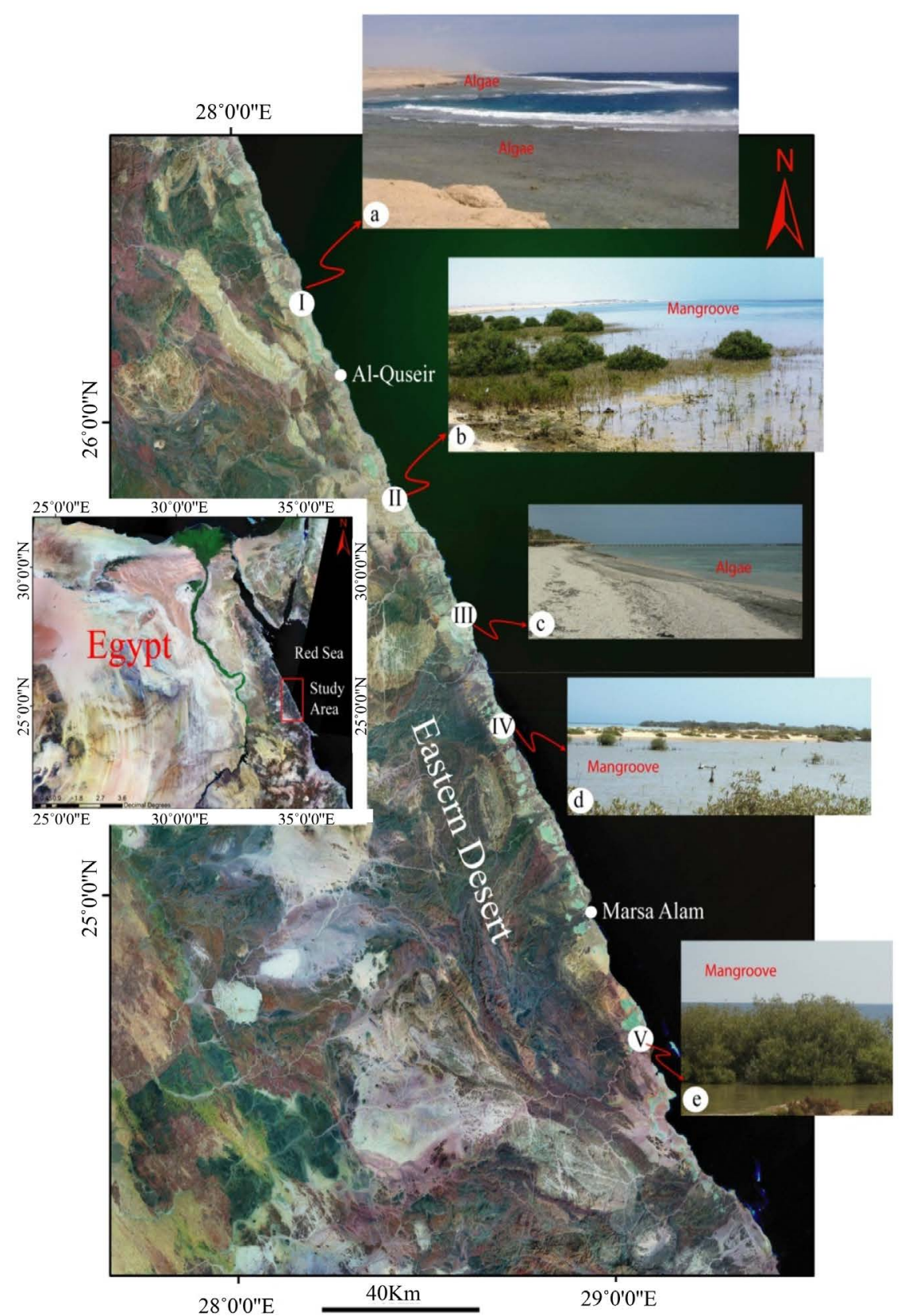

Figure 1. A map study area with photographs of the five collecting sites (from google earth).

Species of osracods were examined in details to identify to the species level. As well as some references used in of ostracods [1] [6] [7] Bonaduce et al. [2]; Bonaduce et al. [3] [8] [9] [10]; Nishath et al. [11] [12] and [5].

Abbreviations used: $R V=$ right valve, $L V=$ left valve, $L=$ length, $H=$ height.

\section{Results}

\subsection{The Water Parameters}

During the present study, sea water temperature, salinity, $\mathrm{pH}$, dissolved oxygen, 
electrical conductivity and the total dissolved salts (TDS) are summarized in Table 2 . The water temperature in the area under investigation ranged between $28.8^{\circ} \mathrm{C}-34.7^{\circ} \mathrm{C}$. Moreover, the salinity is high and fluctuated between 41.22 to $42.75 \%$. By comparing the $\mathrm{pH}$ values in all collection sites showing small variations and ranged from 8.27 to 8.65 , this is indicated that the studied area is weakly alkaline. The dissolved oxygen in the study area ranged from 6.9 to 8.8 $(\mathrm{mg} / \mathrm{l})$ and the electrical conductivity fluctuates between 63.2 and 64.5. Additionally, the total dissolved salts (TDS) were observed in the range of 37.98 to 39 . $49 \mathrm{~g} / \mathrm{l}$. According to the above result, the ecological factors have an important role in the distribution and numbers of Ostraccoda in the Red Sea.

Nishath et al. [13] reported that, salinity has a direct effect on the number and abundance of specimens in marine and marginal marine environments. Moreover, [14] stated that dissolved oxygen considered one of the factors contributing to the abundance of some living inhabitants.

\subsection{Distribution of Ostracod Species}

Twenty ostracod species have been collected from five sites along the region from Al-Quseir to Marsa Alam. The recorded species belong to Order Podocopida, ten families and sixteen genera. The collecting ostracod species were Loxoconcha ghardaqensis, Loxoconcha ornatovalve, Loxoconcha gisellae, Loxoconchella dorsobullata, Xestoleberis ghardaqe, Xestoleberis rotunda, Paranesidea fracticorallicola Neonesidea schulzi, Neonesidea aff. michaelseni, Mosella stariata, Hiltermannicythere rubrimaris, Cyprideis littoralis, Hemicytherura vidensaegyptica, Tanella gracilis, Callistocythere arcana, Leptocythere arinecola, Quadracythere borchersi, Caudites sublevis, Paradoxostoma altecaudatum, Ghardaglaia triebeli. As well as, their distribution over the sites of collection was summarized in Table 3.

The most common species in the collecting region are Loxoconcha ghardaqensis, Xestoleberis rotunda, Paranesidea fracticorallicola, Tanella gracilis and Neonesidea schulzi, whereas, Hemicytherura videns aegyptica and Caudites sublevis occurred in few numbers. Ostracods are highly diverse in the first and

Table 2. Water temperature $\left({ }^{\circ} \mathrm{C}\right)$, salinity (pp), dissolved oxygen (DO), $\mathrm{pH}$ and total dissolved salts (TDS) and electrical conductivity $(\mathrm{mS} / \mathrm{cm})$ at the sampling stations.

\begin{tabular}{ccccccc}
\hline Sites & $\begin{array}{c}\text { Water T. } \\
\left({ }^{\circ} \mathrm{C}\right)\end{array}$ & $\begin{array}{c}\text { Salinity } \\
(\%)\end{array}$ & $\begin{array}{c}\mathrm{DO} \\
(\mathrm{mg} / \mathrm{l})\end{array}$ & $\mathrm{pH}$ & $\begin{array}{c}\text { TDS } \\
(\mathrm{g} / \mathrm{l})\end{array}$ & $\begin{array}{c}\text { Electrical } \\
\text { Conductivity }(\mathrm{mS} / \mathrm{cm})\end{array}$ \\
\hline North Wadi Syatin (I) & 28.8 & 42.13 & 6.9 & 8.27 & 37.98 & 63.2 \\
$\begin{array}{c}\text { North Wadi Asal (II) } \\
\text { South Wadi Um Gerifat }\end{array}$ & 33.4 & 41.65 & 7.8 & 8.65 & 38.21 & 64.1 \\
$\begin{array}{c}\text { (III) } \\
\begin{array}{c}\text { South Wadi Abu } \\
\text { Dabbab (IV) }\end{array}\end{array}$ & 32.6 & 41.22 & 7.2 & 8.48 & 38.81 & 63.7 \\
$\begin{array}{c}\text { South Wadi Abu } \\
\text { Ghusun (V) }\end{array}$ & 34.7 & 42.48 & 8.8 & 8.53 & 39.37 & 63.9 \\
\hline
\end{tabular}


Table 3. Distribution the individual numbers of ostracod species in five collecting sites.

\begin{tabular}{|c|c|c|c|c|c|c|c|}
\hline \multirow{3}{*}{$\begin{array}{c}\text { Families } \\
\text { Loxoconchidae }\end{array}$} & \multirow{3}{*}{$\begin{array}{l}\text { Species } \\
\text { oncha ghardaqensis }\end{array}$} & \multicolumn{5}{|c|}{ Collection sites } & \multirow{3}{*}{$\begin{array}{r}\text { Total } \\
748\end{array}$} \\
\hline & & \multicolumn{5}{|c|}{ Site ISite IISite III Site IV Site V } & \\
\hline & & 344 & 51 & 189 & 86 & 78 & \\
\hline & 2-Loxoconcha ornatovalve & 27 & - & 138 & 68 & 35 & 268 \\
\hline & 3-Loxoconcha gisellae & 26 & 12 & 45 & 7 & - & 90 \\
\hline & 4-Loxoconchella dorsobullata & 154 & 16 & 75 & 35 & 57 & 337 \\
\hline \multirow[t]{2}{*}{ Xestoleberdidae } & 5-Xestoleberis ghardaqe & 62 & 29 & 34 & 39 & 44 & 208 \\
\hline & 6-Xestoleberis rotunda & 189 & 49 & 247 & 92 & 62 & 639 \\
\hline \multirow[t]{3}{*}{ Baidiidae } & 7-Paranesidea fracticorallicola & 213 & 62 & 176 & 87 & 49 & 587 \\
\hline & 8-Neonesidea schulzi & 44 & 37 & 293 & 34 & - & 408 \\
\hline & 9-Neonesidea aff. Michaelseni & 26 & - & 14 & 52 & 16 & 108 \\
\hline \multirow[t]{2}{*}{ Trachyleberididae } & 10-Moosella striata & 69 & 38 & 68 & 118 & 65 & 358 \\
\hline & 11-Hiltermannicythere rubrimaris & 75 & - & 82 & 41 & 36 & 234 \\
\hline Cytherideidae & 12-Cyprideis littoralis & 21 & 70 & 17 & - & 49 & 157 \\
\hline Cytheruridae & 13-Hemicytherura videns aegyptica & 7 & - & 22 & 11 & 4 & 44 \\
\hline \multirow[t]{3}{*}{ Leptocytheridae } & 14-Tanella gracilis & 206 & 10 & 146 & 57 & 16 & 435 \\
\hline & 15-Callistocythere arcane & 32 & 80 & 16 & 27 & 37 & 192 \\
\hline & 16-Leptocythere arinecola & 83 & 22 & 51 & 15 & 24 & 195 \\
\hline \multirow[t]{2}{*}{ Hemicytheridae } & 17-Quadracythere borchersi & - & 91 & 38 & 108 & 79 & 316 \\
\hline & 18-Caudites sublevis & 9 & - & 23 & 17 & - & 49 \\
\hline Paradoxostomatidae & 19-Paradoxostoma altecaudatum & 33 & 8 & 49 & 26 & 19 & 135 \\
\hline \multirow[t]{3}{*}{ Paracyprididae } & 20-Ghardaglaia triebeli & 98 & 20 & 172 & 16 & 35 & 341 \\
\hline & Total & 1718 & 595 & 1895 & 936 & 705 & 5849 \\
\hline & Ratio & 29.37 & 10.17 & 32.39 & 16 & 12.05 & \\
\hline
\end{tabular}

the third sites constituting $29.37 \%$ and $32.39 \%$, respectively. While, the second, fourth and fifth sites are less diverse in ostracods constituting $10.17 \%$, 16\%, $12.05 \%$, respectively. On the other hand, the three genera Loxoconcha, Neonesidea and Xestoleberis displayed a high diversity of species.

The plants on the sites under study deliver food and shelter for ostracod species [5] [15] [16] [17]. Moreover, [18] noted that the density of ostracods fluctuates according to the grade of structure complexity of algae.

In the current study, it is generally observed that sites which are covered with macro-algae are occupied by dense ostracods (e.g., site I and site III). Similarly, collecting sites which covered with mangrove trees have less numbers of ostracods (e.g., sites II, IV and V).

\subsection{Systematic Descriptions}

The current study presents identification of twenty species of Ostracoda from 
El-Quseir to Marsa Alam on the West Coast of Red Sea. These species belong to one order, ten families and fourteen genera. The total numbers and percentages of all identified species are summarized in Table 2.

Class: Ostracoda Latreille 1806.

Order: Podocopa G. W. Müller 1894.

Suborder: Podocopida Sars 1866.

Family: Loxoconchidae Sars 1925.

Subfamily: Loxoconchinae Sars 1825.

Genus: Loxoconcha Sars, 1866.

\subsubsection{Loxoconcha ghardaqensis Hartmann, 1964 (Figures 2(a)-(c))}

Loxoconcha ghardaqensis [1], pl. 15-18, Figures 67-82.

Loxocorniculum ghardaqensis Hartmann: [19], p. 254.

Loxoconcha ghardaqensis Hartmann: [20], pl. IV, Figure 13.

Loxocorniculum ghardaqensis Hartmann: [4], p. 87, pl. 1, Figure 13.

Loxoconcha ghardaqensis Hartmann: [12], Figure 8: 121-126.

Measurements: Female; $\mathrm{L}=0.57 \mathrm{~mm}, \mathrm{H}=0.35 \mathrm{~mm}$, Male; $\mathrm{L}=0.65 \mathrm{~mm}, \mathrm{H}=$ $0.39 \mathrm{~mm}$.

Geographical distribution: Red Sea.

Occurrence: Loxoconcha ghardaqensis is widely distributed species in the Red Sea and occurs with several numbers in the first and third sites.

Ecology: This species found in shallow water and occurred in large numbers in algae. The suitable environmental factors for this species are: Water temperature ranges between $28.8^{\circ} \mathrm{C}-32.6^{\circ} \mathrm{C}$, $\mathrm{pH}$ varies between 8.27 and 8.48 , salinity fluctuates from $42.13 \%$ o to $41.22 \%$. Also, dissolved oxygen ranges from 6.9 to $7.2(\mathrm{mg} / \mathrm{l})$.

Remarks: In our specimens the ornamentation consists of concentrically reticulation arranged in circles, while in L. ghardaqensis of Bonaduce et al. [2] the reticulation is arranged randomly. Also, the caudal process at the posterior margin of our specimen is striated and has a rectangular shape resembling with that of [12], but differs from that of Bonaduce et al. [2]. Our specimens are bigger in size than that of [12].

3.3.2. Loxoconcha ornatovalve Hartmann, 1964 (Figure 2(d), Figure 2(e)) Loxoconcha ornatovalvae [1], pl. 20, Figures 92-100.

Loxoconcha ornatovalvae Hartmann: [19], pls. 1, 2, 3, Figures 1k, 2k, 3k.

Loxoconcha ornatovalvae Hartmann: Bonaduce et al. [2], pl. 10, Figure 9.

Loxoconcha ornatovalvae Hartmann: [21], p. 236, Figure 2a.

Loxoconcha ornatovalvae Hartmann: [22], p. 1189.

Loxoconcha ornatovalvae Hartmann: [10], p. 66, Figure 32.

Loxoconcha ornatovalvae Hartmann: [12], Figure 8: 109-116.

Dimentions: $\mathrm{L}=0.40 \mathrm{~mm}, \mathrm{H}=0.20 \mathrm{~mm}$.

Geographical distribution: Red Sea, Persian Gulf and the West Coast of India. 


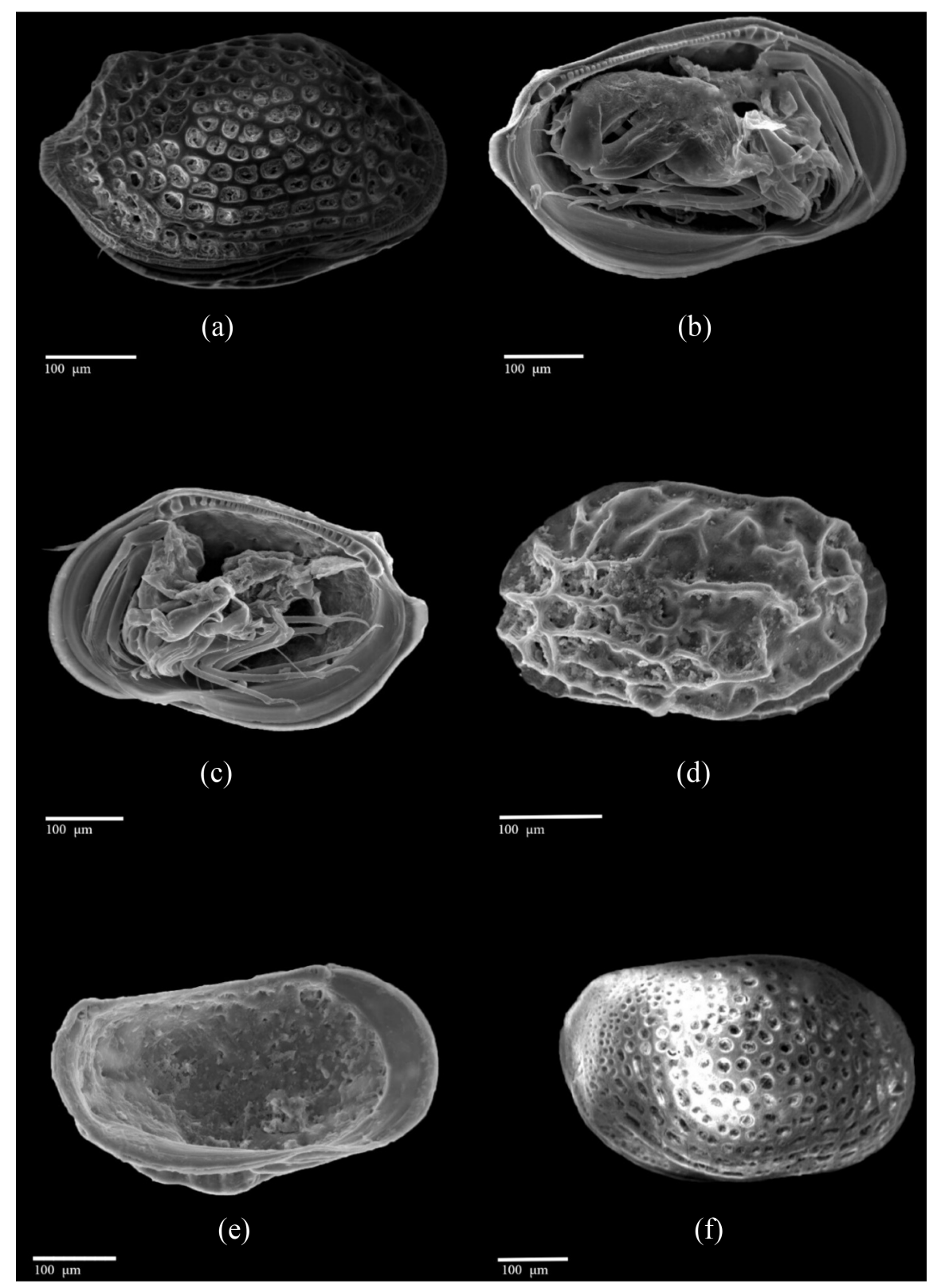

Figure 2. Scanning Electron Microscope showing. (a) External view of female carapace of Loxoconcha ghardaqensis, (b): Internal view of left valve of male of L. ghardaqensis (c) Internal view of right valve of female of L. ghardaqensis (d) External view of left valve of Loxoconcha ornatovalve (e) Internal view of left valve of $L$. ornatovalve (f) External view of right valve of Loxoconcha gisellae.

Occurrence: L. ornatovalvae is widely distributed species in the Red Sea and occurs with several numbers in the third site. While, it is occurring in fewer numbers in the first, fourth and fifth sites and absent from the second site.

Ecology: This species found in shallow water and occurred in large numbers in algae. The appropriate environmental factors for this species are: Water temperature equal $32.6^{\circ} \mathrm{C}, \mathrm{pH}$ is 8.48 , salinity is $41.22 \%$. Also, dissolved oxygen is $7.2(\mathrm{mg} / \mathrm{l})$. 
Remarks: The caudal process of our specimen is smaller than that of Bonaduce et al. [1] [2] and [12]. As well as, our species differs from that of [10] in the lateral ornamentation and dorsal margin, but resembles it in the shape of caudal process at the dorsal margin.

\subsubsection{Loxoconcha gisellae Bonaduce et al, 1980 (Figure 2(f))}

Loxoconcha gisellae Bonaduce et al. [23], pl. 3, Figures 1-8.

Loxoconcha gisellae Bonaduce et al:: Munef et al. [24], pl. 4, Figures 65-70.

Measurements: Length $=0.58 \mathrm{~mm}$, Height $=0.31 \mathrm{~mm}$

Geographical distribution: Red Sea.

Occurrence: Loxoconcha gisellae occurs in small numbers in four sites and absent from the fifth one.

Ecology: L. gisellae found in shallow water and the appropriate environmental factors for flourishing this species are: Water temperature equal $32.6^{\circ} \mathrm{C}, \mathrm{pH}$ is 8.48, salinity is $41.22 \%$. Also, dissolved oxygen is $7.2(\mathrm{mg} / \mathrm{l})$.

Remarks: The current species are closely related to that of [19] and larger than it. But, the caudal process of our species is shorter than that of [19] and the reticulation of the dorsal margin is less obvious. Also, the present species resemble Loxoconcha gurneyi [21], but differ from it in carapace ornamentation and outlines. Our species are closely related to $L$. amygdalanux but differs in the sinus ventral margin.

Genus: Loxoconchella Triebel, 1954

\subsubsection{Loxoconchella dorsobullata Hartmann, 1964 (Figure 3(a),} Figure 3(b))

Loxoconchella dorsobullata [1], pls. 21- 22, Figures 101-113.

Loxoconchella sp. [25], Figure 51.

Loxoconchella dorsobullata Hartmann: Bonaduce et al. [1], pl. 10: Figure 10.

Loxoconchella dorsobullata Hartmann: [8], pl. 2, Figures 6-9.

Measurements: $\mathrm{L}=0.57 \mathrm{~mm}, \mathrm{H}=0.35 \mathrm{~mm}$

Geographical distribution: Red Sea (Hurghada, Gulf of Aqaba and Jeddah in Saudi Arabia).

Occurrence: $L$. dorsobullata is widely distributed species in the Red Sea and occurs with several numbers.

Ecology: The present species found in shallow water and occurred in large numbers in algae. The suitable ecological factors for this species are: Water temperature equal $28^{\circ} \mathrm{C}, \mathrm{pH}$ is 8.27 , salinity is $42.13 \%$. Also, dissolved oxygen is 6.9 $(\mathrm{mg} / \mathrm{l})$

Remarks: Our specimens ( $L$. dorsobullata) is larger than those of [1] and [8]. Moreover, the caudal process of our species resembles that of [8] and more obvious than that of Bonaduce et al. [2]. The pores on the carapace of $L$. dorsobullata in [8] are more obvious than our specimen.

Family: Xestoleberididae Sars 1926

Subfamily: Xestoleberidinae Sars 1928.

Genus: Xestoleberis Sars, 1866. 


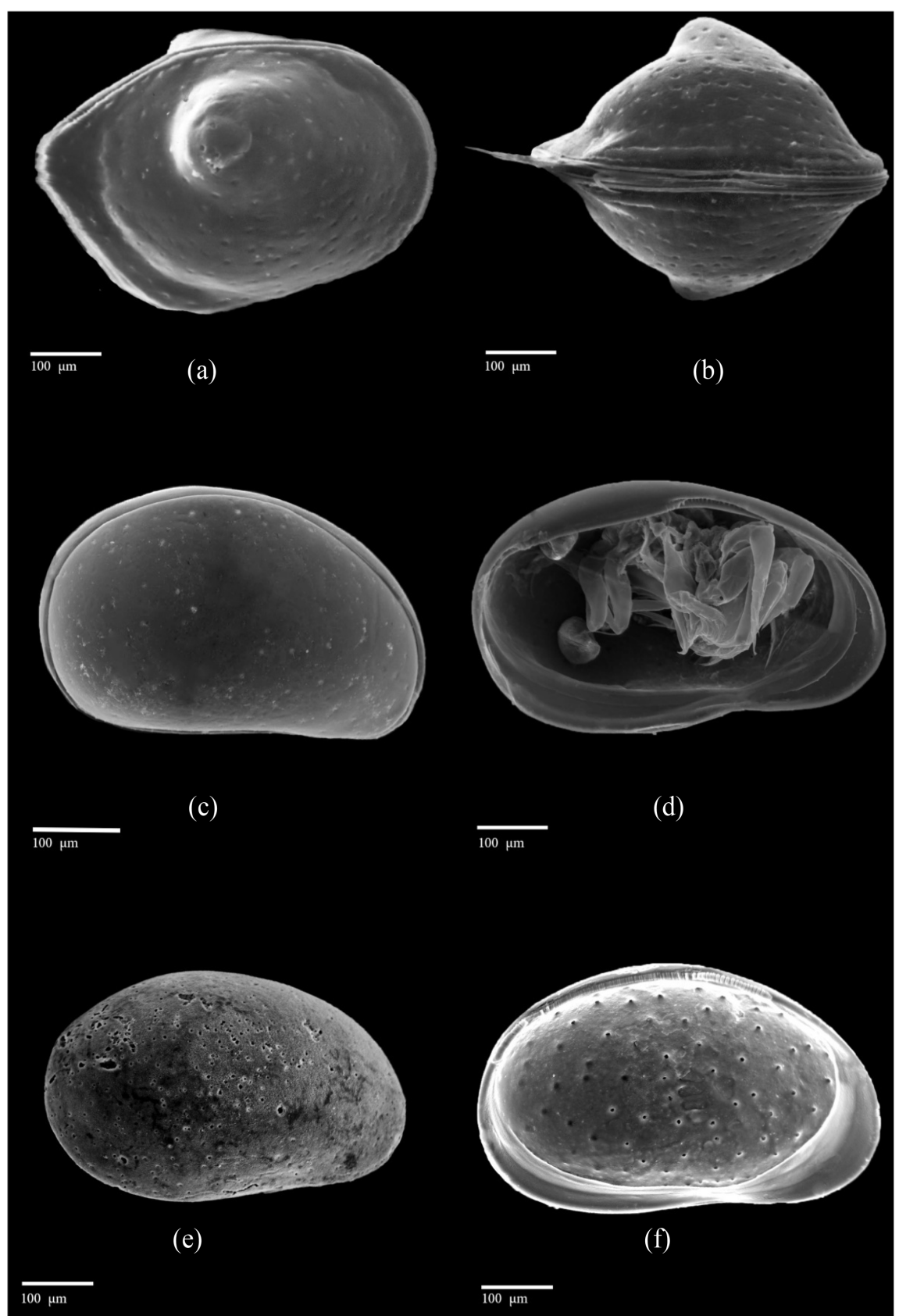

Figure 3. Scanning Electron Microscope showing. (a) Lateral view of carapace of Loxoconchella dorsobullata (b) Ventral view of carapace of L. dorsobullata (c) Lateral view of carapace Xestoleberis ghardaqae (d) Internal view of right valve of female of $X$. ghardaqae (e) External view of left valve of $X$. rotunda (f) Internal view of right valve of $X$. rotunda.

\subsubsection{Xestoleberis ghardaqe Hartmann, 1964 (Figure 3(c), Figure 3(d))}

Xestoleberis ghardaqae [1], pl. 2.

Xestoleberis ghardaqe Hartmann: Bonaduce et al. [2], pl. 11: Figure 11.

Xestoleberis ghardaqae Hartmann: [12], Figure 13.

Xestoleberis rotunda Hartmann: [5], pl. 1, Figure 8.

Diementions: L: $0.36 \mathrm{~mm}, \mathrm{H}: 0.20 \mathrm{~mm}$. 
Geographical distribution: Red Sea.

Ecology: $X$. ghardaqae occurs in shallow water in moderate numbers in collection sites.

Occurrence: The present species occurred in all collection sites.

Remarks: The dorsal margin of our specimen ( $X$. ghardaqae) is less arched and smaller in size than that of [12]. Moreover, the anterior margin of our specimens is wider than that of [12] and Bonaduce et al. [2].

\subsubsection{Xestoleberis rotunda Hartmann, 1964 (Figure 3(e), Figure 3(f))}

Xestoleberis rotunda [1], pls.24, 28, 29, Figures 156-163.

Xestoleberis rotunda [19], pls.1, 2, 3, Figures 1c, 2c, 3.

Xestoleberis rotunda Hartmann: Bonaduce et al. [2], Pl. 11: Figure 12.

Xestoleberis rotunda Hartmann: [5], Pl. 1, Figure 18.

Xestoleberis rotunda Hartmann: [12], Figure 13: 199-206.

Size: L: $0.57 \mathrm{~mm}, \mathrm{H}: 0.38 \mathrm{~mm}$.

Geographical Distribution: Indian Ocean, Red Sea and Persian Gulf.

Occurrence: is widely distributed species in the Red Sea and occurs with several numbers in the first and third sites.

Ecology: This species found in shallow water and occurred in large numbers in algae. The suitable environmental factors for this species are: Water temperature ranges between $28.8^{\circ} \mathrm{C}-32.6^{\circ} \mathrm{C}, \mathrm{pH}$ varies between 8.27 and 8.48 , salinity fluctuates from $42.13 \%$ o to $41.22 \%$. Also, dissolved oxygen ranges from 6.9 to $7.2(\mathrm{mg} / \mathrm{l})$.

Remarks: Xestoleberis rotunda is larger than that of [12] and its anterior margin narrower than it. Furthermore, the dorsal margin of $X$. rotunda is more arched than that of our species.

Superfamily: Bairdiacea Sars, 1888.

Family: Bairdiidae Sars, 1888.

Genus: Paranesidea Maddocks, 1969.

\subsubsection{Paranesidea fracticorallicola Maddocks, 1969 (Figures 4(a)-(d))}

Paranesidea fracticorallicola Maddocks [6] [7], Figures 16A-I, 17A-D, 18 A. Paranesidea fracticorallicola Maddocks: Bonaduce et al. [3], pls.1, 2, Figure 1F, 5-6.

Paranesidea fracticorallicola Maddocks: [26], pls.3, 11, Figures 7-10.

Paranesidea fracticorallicola Maddocks: [11], pl. 1, Figure 7.

Measurements: $\mathrm{L}=0.94 \mathrm{~mm}, \mathrm{H}=0.7 \mathrm{~mm}$

Geographical Distribution: Nosy Be, Madagascar, Red Sea and Gulf of Oman.

Occurrence: The current species are widely distributed species in the Red Sea and occurs with several numbers in the first and third sites.

Ecology: This species habiting shallow water and occurred in large numbers in algae. The suitable environmental factors for this species are: Water temperature 


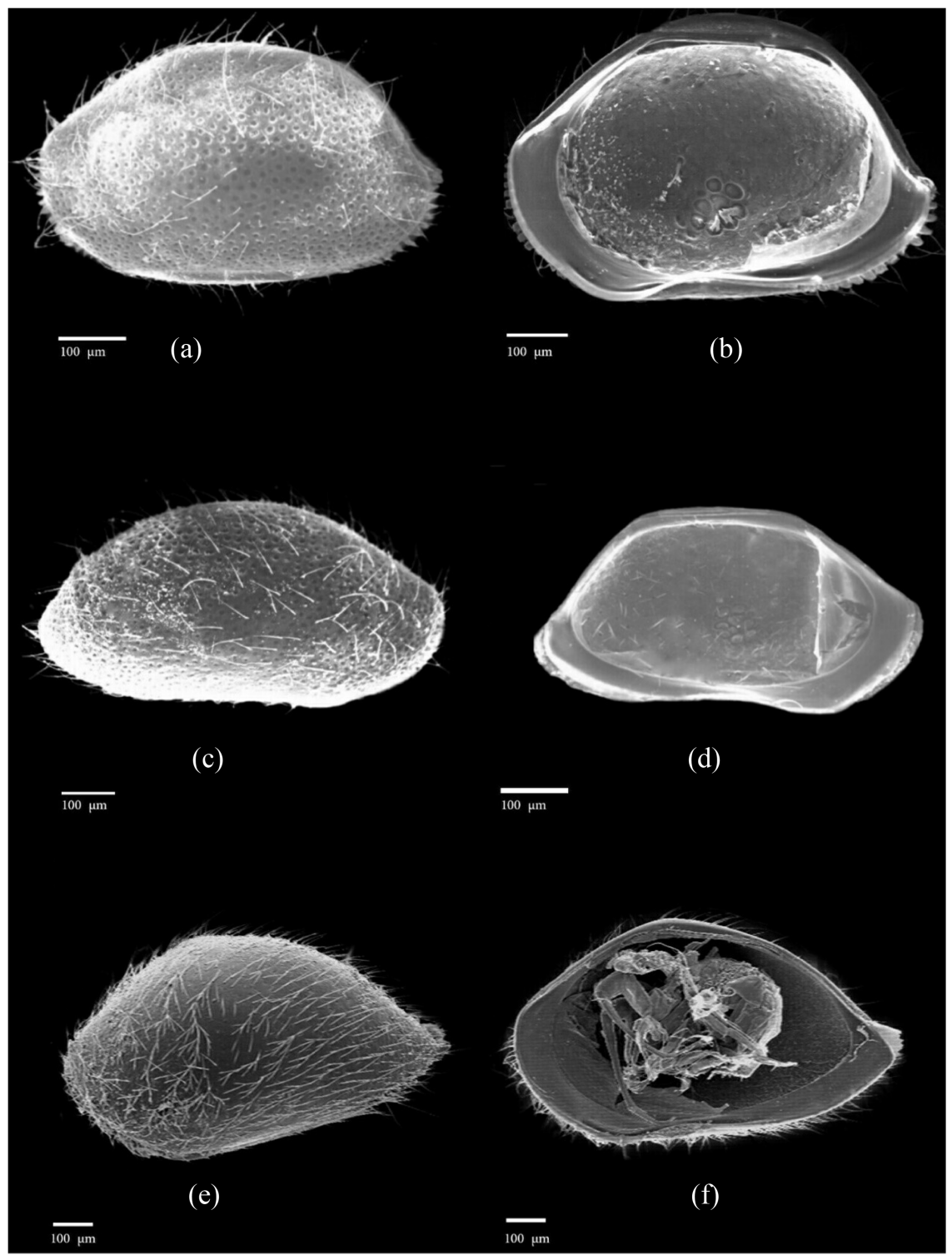

Figure 4. Scanning Electron Microscope showing. (a) External view of left valve of Paranesidea fracticorallicola (b) Internal view of left valve of $P$. fracticorallicola (c) External view of right valve of $P$. fracticorallicola (d) Internal view of right valve of $P$. fracticorallicola (e) External view of left valve Neonesidea schulzi (f) Internal view of right valve of male of $N$. schulzi.

ranges between $28.8^{\circ} \mathrm{C}-32.6^{\circ} \mathrm{C}, \mathrm{pH}$ varies between 8.27 and 8.48 , salinity fluctuates from $42.13 \%$ to $41.22 \%$. Also, dissolved oxygen ranges from 6.9 to 7.2 (mg/l).

Remarks: The ornamentation of Paranesidea fracticorallicola carapace consists of circular punctate be wide at the center and narrow at the peripheral margins. The left valve of present species is longer than the right one and overlap it. Our species have blunt spines at the dorsal margin, which are absent from that of Bonaduce et al. [27].

Genus: Neonesidea Maddocks, 1969a 
3.3.8. Neonesidea schulzi (Hartmann, 1964) (Figure 4(e), Figure 4(f))

Triebelina schulzi [1], pls. 4-5, Figures 14-22.

Neonesidea schulzi (Hartmann): [6] [7], Figures 4a-d, 5-6.

Neonesidea schulzi (Hartmann): [28], pl. 7, Figures 9-11.

Neonesidea schulzi (Hartmann): Bonaduce et al. [2], pl. 4, Figure 6.

Neonesidea schulzi (Hartmann): [29], pl. IV, Figure 2.

Neonesidea schulzi (Hartmann): [30], pl. 2, Figures 1-10.

Neonesidea schulzi (Hartmann): [12], pls. 2-9.

Measurements: L: $1.200 \mathrm{~mm}, \mathrm{H}: 0.68 \mathrm{~mm}$.

Geographical distribution: Gulf of Aden, Red Sea, east coast of Africa, Indo-pacific region.

Occurrence: The current species are distributed species in the Red Sea and occurs with several numbers in the third site.

Ecology: This species found in shallow water and occurred in large numbers in algae. The appropriate environmental factors for this species are: Water temperature equal $32.6^{\circ} \mathrm{C}, \mathrm{pH}$ is 8.48 , salinity is $41.22 \%$. Also, dissolved oxygen is $7.2(\mathrm{mg} / \mathrm{l})$.

Remarks: This species is widely distributed in the Red Sea and occurred in several numbers. It is characterized by having seven leaf-like setae at its posterior margin as that of [1]. Moreover, our specimen has numerous long sensillae on its carapace surface, while these sensillae absent in N. schulzi of [12].

\subsubsection{Neonesidea aff. michaelseni Hartmann, 1982 (Figure 5(a))}

Neonesidea michaelseni [31], Figures 5-10, 47-49, pl. 6.

Neonesidea michaelseni [32], Figures 1-4, 25-28, pl. 1.

Neonesidea michaelseni Hartmann: [12], Figures 2: 7, 8.

Measurements: L: $0.94 \mathrm{~mm}$; H: $0.62 \mathrm{~mm}$.

Geographical distribution: Australia, Polynesia, Red Sea.

Ecology: This species found in shallow water and occurred in large numbers in algae. The appropriate environmental factors for this species are: Water temperature equal $34.5^{\circ} \mathrm{C}, \mathrm{pH}$ is 8.53 , salinity is $42.48 \%$. Also, dissolved oxygen is $8.8(\mathrm{mg} / \mathrm{l})$.

Occurrence: This species absent from the second site and occurred in fewer numbers in the remaining sites.

Remarks: The shell shape of this species resembles that of $N$. michaelseni. Our species are larger than the ones from Polynesia and from Australia. Also, the present species are larger than that of [12].

Family: Trachyleberididae Sylvester-Bradley, 1948

Subfamily: Trachyleberidinae Sylvester-Bradley, 1948

Genus: Moosella Hartmann, 1964

\subsubsection{Moosella striata Hartmann, 1964 (Figure 5(b), Figure 5(c))}

Moosella striata [1], pls. 46, 50-51, Figures 270-273, 289-297.

Moosella striata Hartmann: Bonaduce et al. [2], p. 382, 


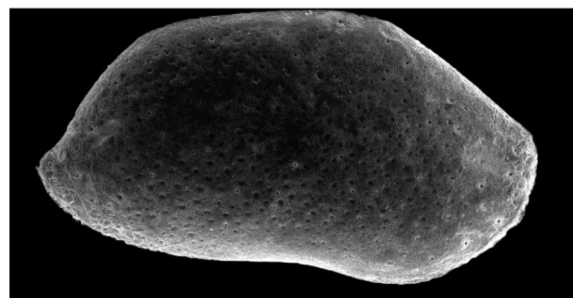

(a)

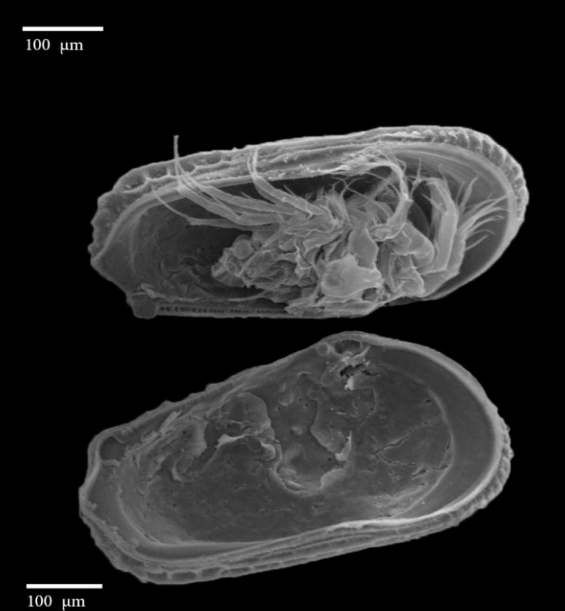

(c)

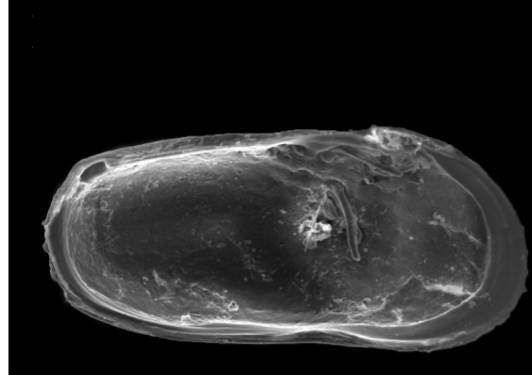

(e)

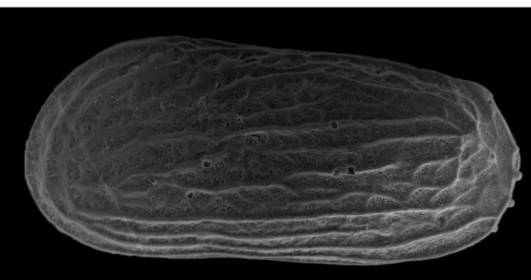

(b)

\section{$\overline{100 \mu \mathrm{m}}$}

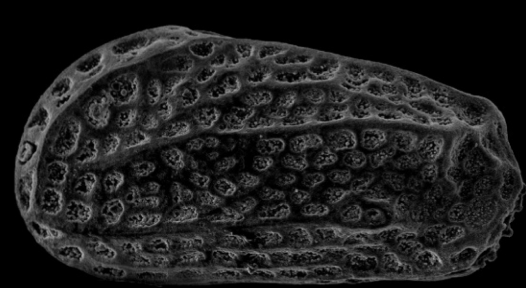

$100 \mu \mathrm{m}$

(d)

\section{$\overline{100 \mu \mathrm{m}}$}

Figure 5. Scanning Electron Microscope showing. (a) External view of right valve ofNeonesidea michaelseni (b) External view of left valve of Moosella striata (c) Internal view of opening carapace of Moosella striata (d) External view of left valve of Hiltermannicythere rubrimaris (e) Internal view of left valve Hiltermannicythere rubrimaris (f) Internal view of right valve of Cyprideis littoralis.

Moosella striata Hartmann: Bonaduce et al. [27], pl. 4, Figures 1-4.

Moosella striata Hartmann: [29], pl. IV, Figure 7.

Moosella striata Hartmann: [33], pl. 16, Figures 302-307.

Moosella striata Hartmann: [4], pl. 1, Figure 16.

Moosella striata Hartmann: [12], pls. 11, 175-179.

Size: L: $0.86 \mathrm{~mm}, \mathrm{H}: 0.45 \mathrm{~mm}$.

Geographical distribution: Gulf of Aqaba (Red Sea), Kenya.

Ecology: The current species found in shallow water and occurred in large numbers in algae. The suitable environmental factors for this species are: Water 
temperature equal $34.5^{\circ} \mathrm{C}, \mathrm{pH}$ is 8.53 , salinity is $42.48 \%$. Also, dissolved oxygen is $8.8(\mathrm{mg} / \mathrm{l})$.

Occurrence: This species occurred in large numbers in the fourth site and moderate numbers in the remaining sites.

Remarks: The carapace of Moosella striata characterized by the presence of similar striated ridges without fossae, however, the carapace surface of the same species of [12] intercalated with fossae. Moreover, the present species is larger than that of M. striata which recorded by [12].

Subfamily: Phacorhabdotinae Gründel, 1969

Genus: Hiltermannicythere Bassiouni, 1970

\subsubsection{Hiltermannicythere rubrimaris (Hartmann, 1964) (Figure 5 (d),} Figure 5(e))

Hiltermannicythere rubrimaris (Hartmann), Bonaduce et al. [2], pl. 5, Figure

1.

Hiltermannicythere rubrimaris (Hartmann), Bonaduce et al. [27], pl. 6, Figure 10.

Hiltermannicythere rubrimaris (Hartmann), [33], pl. 14, Figures 264-269.

Hiltermannicythere rubrimaris (Hartmann), [12], Figure 11: 172-174.

Size: L: $0.86 \mathrm{~mm}, \mathrm{H}: 0.38 \mathrm{~mm}$,

Geographical distribution: Red Sea, Kenya, Yemen.

Occurrence: The current species are moderately distributed species in the Red Sea and occurs with moderate numbers in the first and third sites. While, it is occurring in fewer numbers in the fourth and fifth sites and absent from the second.

Ecology: This species found in shallow water and occurred in large numbers in algae. The suitable environmental factors for this species are: Water temperature ranges between $28.8^{\circ} \mathrm{C}-32.6^{\circ} \mathrm{C}, \mathrm{pH}$ varies between 8.27 and 8.48 , salinity fluctuates from $42.13 \%$ to $41.22 \%$. Also, dissolved oxygen ranges from 6.9 to $7.2(\mathrm{mg} / \mathrm{l})$.

Remarks: The individuals of Genus Hiltermannicythere have more resembled to those of Genus Mosella. Our specimen Hiltermannicythere rubrimaris has more resembled to that of Bonaduce et al. [27] and larger than the ones of [12] and those reported from Kenya.

Family: Cytherideidae Sars, 1925

Subfamily: Cytherideinae Sars, 1925

Genus: Cyprideis Jones, 1857

\subsubsection{Cyprideis littoralis Brady, 1868 (Figure 5(f))}

Cyprideis littoralis Brady: [1], Figures 41-45, pl. 10.

Cyprideis littoralis Brady: [5], pls. 1, 2, Figures 1, 12.

Diementions: $\mathrm{L}=0.78 \mathrm{~mm}, \mathrm{H}=0.47 \mathrm{~mm}$

Geographical Distribution: Red Sea.

Occurrence: The current species are distributed in four collecting sites and 
occurs with large numbers in the second site.

Ecology: This species found in shallow water and occurred in large numbers in algae. The suitable environmental factors for this species are: $33.4^{\circ} \mathrm{C}$ water temperature, $8.65 \mathrm{pH}, 42.13 \%$ o salinity and the dissolved oxygen is $7.8(\mathrm{mg} / \mathrm{l})$.

Remarks: The present species Cyprideis littoralis differs from that of [5] in having a large blunt spine at posterior margin.

Family: Cytheruridae G.W. Müller 1894.

Subfamily: Cytherurinae G.W. Müller 1894.

Genus: Hemicytherura Elofson, 1941.

\subsubsection{Hemicytherura videns aegyptica Hartmann, 1964 (Figure 6(a)-(d))}

Hemicytherura videns aegyptica [1], pl. 13, Figures 61, 62, 66.

Hemicytherura videns Hartmann: [34], Figure 1.

Hemicytherura aegyptica Hartmann: [35], pp. 7-12

Hemicytherura videns aegyptica Hartmann: [12], Figure 4.

Size: Male: $\mathrm{L}=0.34 \mathrm{~mm}, \mathrm{H}=0.19 \mathrm{~mm}$, Female: $\mathrm{L}: 0.28 \mathrm{~mm}, \mathrm{H}: 0.20 \mathrm{~mm}$

Occurrence: It occurred with fewer numbers in four sites and absent from the second one.

Geographical distribution: Red Sea, Persian Gulf and Indian Ocean.

Remarks: This species is closely related to $H$. videns which recorded by [1].

Family: Leptocytheridae Hanai, 1957

Genus: Tanella Kingma, 1948.

\subsubsection{Tanella gracilis Kingma, 1948 (Figure 6(e), Figure 6(f))}

Tanella gracilis [36], pl. 10, Figure 7.

Tanella cf. gracilis Kingma: [19], pls. 1-3, Figure 11.

Tanella aff. gracilis Kingma: [37], pl. 2, Figures 35-37.

Tanella gracilis Kingma: [38], pls. 4-13, Figures 108-113.

Tanella gracilis Kingma: [39], pl. 2, Figures J 2-4.

Tanella gracilis Kingma: [40], pl. 7, Figures 11-18.

Tanella gracilis Kingma: [41], pl. 3, Figures 3-7.

Tanella gracilis Kingma: Al-Abdul-Razza et al. [42], et al., Figure 7.

Tanella sp. cf. T. gracilis: Kingma: [43], pl. 6, Figures 5-6.

Tanella gracilis Kingma: [44], Figure 93.

Tanella gracilis Kingma: [45], pls. 3, 4, Figures 3, 4, 17.

Tanella gracilis Kingma: [46], pl. 4, Figures 13-15.

Tanella gracilis Kingma: [47], pl. 1, Figure 7.

Tanella gracilis Kingma: [48], pl. I, Figure 18.

Tanella gracilis Kingma: [49], pl. I, Figure 10.

Tanella gracilis Kingma: Sridhar et al. [50], pl. II, Figure 2.

Tanella gracilis Kingma: Arul et al. [51], pl. 1, Figures 5-6.

Tanella gracilis Kingma: [4], pl. 1, Figure 6.

Tanella gracilis Kingma: Hussain et al. [52], Figure 6, 5.

Tanella gracilisKingma: Gopalakrishna et al. [53], pl. I, Figure 14. 


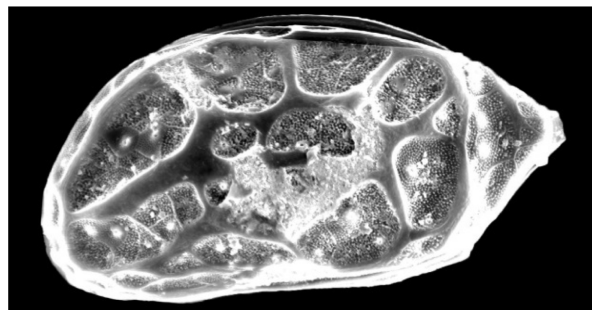

(a)

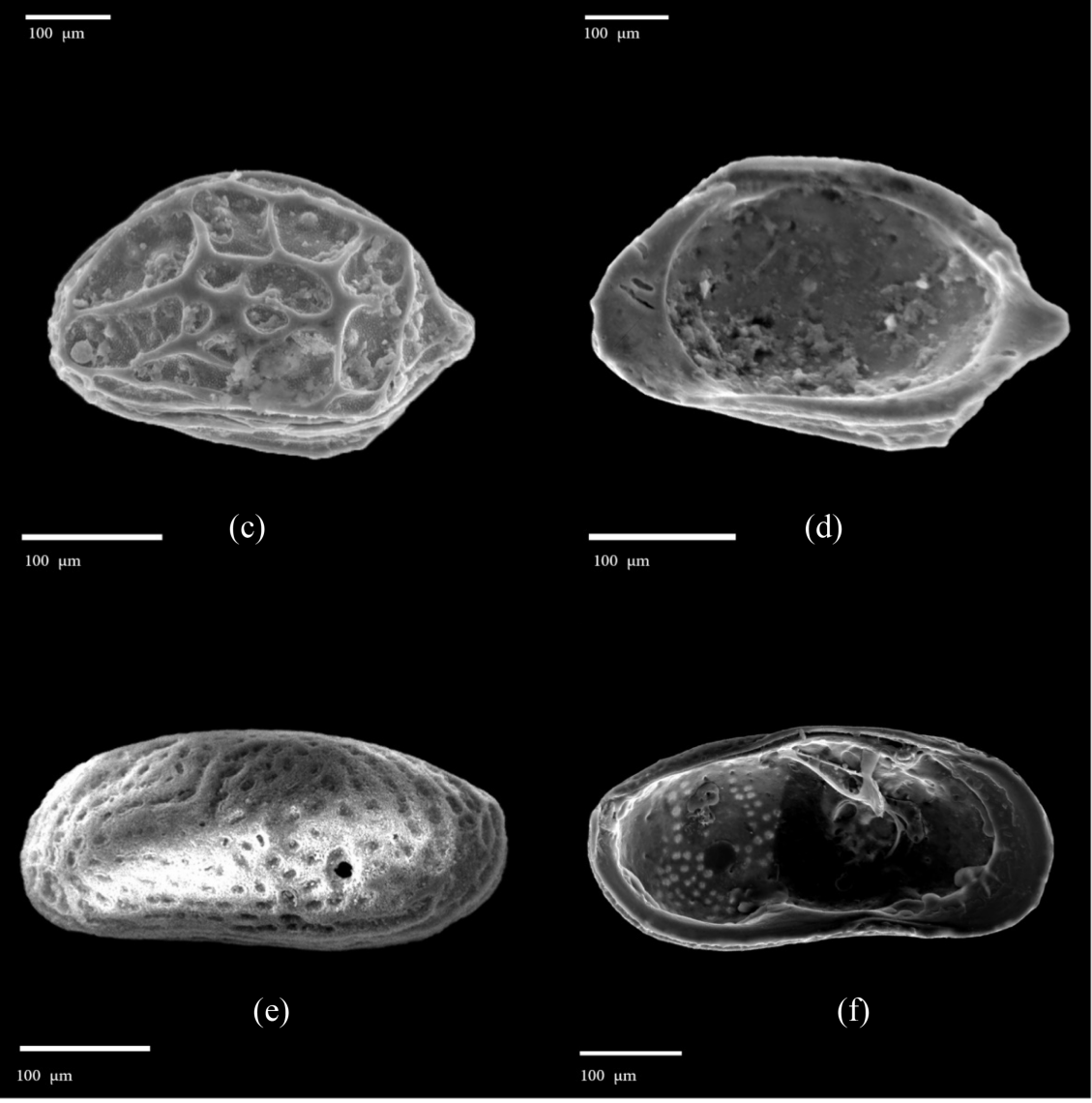

Figure 6. Scanning Electron Microscope showing. (a) External view of left valve of male of Hemicytherura videns aegyptica (b) Internal view of right valve of male $H$. videns aegyptica (c) External view of carapace of female of $H$. videns aegyptica (d) Internal view of right valve of female of $H$. videns aegyptica (e) External view of left valve of Tanella gracilis (f) Internal view of left valve of Tanellagracilis.

\section{Tanella gracilis Kingma: [12], Figure 7: 97-100.}

Size: L: $0.45 \mathrm{~mm}, \mathrm{H}: 0.20 \mathrm{~mm}$.

Occurrence: Tanella gracilis is widely distributed species in the Red Sea and occurs with several numbers in the first and third sites.

Ecology: This species found in shallow water and occurred in large numbers in algae. The suitable environmental factors for this species are: Water temperature ranges between $28.8^{\circ} \mathrm{C}-32.6^{\circ} \mathrm{C}, \mathrm{pH}$ varies between 8.27 and 8.48 , salinity fluctuates from $42.13 \%$ to $41.22 \%$. Also, dissolved oxygen ranges from 6.9 to $7.2(\mathrm{mg} / \mathrm{l})$. 
Geographical distribution: Red Sea, Gulf of Aden, Kuwait, Gulf of Oman, Arabian Gulf, Australia, west African coast, Kenya, Malaya, Andaman Islands, India, Reunion Islands.

Remarks: Our specimens (Tanella gracilis) have a narrower circular punctaes than the ones reported from the Indo-Pacific andfrom those of [12]. Genus: Callistocythere Ruggieri, 1953.

\subsubsection{Callistocythere arcane Bonaduce et al., 1976 (Figure 7(a), Figure 7(b)) \\ Callistocythere arcana Bonaduce et al. [2], p. 378, pl. 3, Figures 3-9. \\ Callistocythere arcana Bonaduce et al., [33], p. 116, pl. 5, Figures 111-113. \\ Callistocythere arcana Bonaduce, [10], p. 58, Figure 11. \\ Callistocythere arcanaBonaduce et al., [54], p. 42, pl. 2, Figure 12. \\ Callistocythere arcana Bonaduce et al., [12], Figure 6: 79-84.}

Size: L $0.43 \mathrm{~mm}, \mathrm{H} 0.22 \mathrm{~mm}$.

Occurrence: The current species are distributed in four of collection sites from the Red Sea and occurs with large numbers in the second site.

Ecology: This species found in shallow water and occurred in large numbers in algae. The suitable environmental factors for this species are: $33.4^{\circ} \mathrm{C}$ water temperature, $8.65 \mathrm{pH}, 42.13 \%$ salinity and the dissolved oxygen is $7.8(\mathrm{mg} / \mathrm{l})$.

Geographical distribution: Red Sea, Persian Gulf, Kenya, Gulf ofAden.

Remarks: The present species are smaller than those of [12] and its anterior margin is narrower than those collected from the Gulf of Aqaba Bonaduce et al. [2].

Genus: Leptocythere Sars, 1925

\subsubsection{Leptocythere arenicola Hartmann, 1964 (Figure 7(c), Figure 7(d))}

Leptocythere (sub. gen. Callistocythere) arenicola [1], pp. 48-50, pl. 12, Figures 52-57, pl. 13, Figures 58, 59.

Leptocythere arenicola Hartmann: Bonaduce et al. [2], p. 378, pl. 3, Figure 2.

Leptocythere arenicola Hartmann: Pugliese et al. [55], pl. 5, Figure 1.

Leptocythere arenicola Hartmann: Munef et al. [24], Plate 4, Figures 53, 54.

Size: L-0.42 mm, H-0.20 mm.

Geographical distribution: Red Sea (Gulf of Aqaba- El Hameira).

Occurrence: The present species are widely distributed in the Red Sea and occurs with several numbers in the first and third sites.

Ecology: This species found in shallow water and occurred in large numbers in algae. The suitable environmental factors for this species are: Water temperature ranges between $28.8^{\circ} \mathrm{C}-32.6^{\circ} \mathrm{C}, \mathrm{pH}$ varies between 8.27 and 8.48 , salinity fluctuates from $42.13 \%$ to $41.22 \%$. Also, dissolved oxygen ranges from 6.9 to $7.2(\mathrm{mg} / \mathrm{l})$.

Remarks: There is no difference could be itemized between our species and those figured by [1] from the Red Sea and Munef et al. [24], from Yemen.

Subfamily: Trachyleberidinae Sylvester-Bradley, 1948

Genus: Quadracythere Hornibrook, 1952 


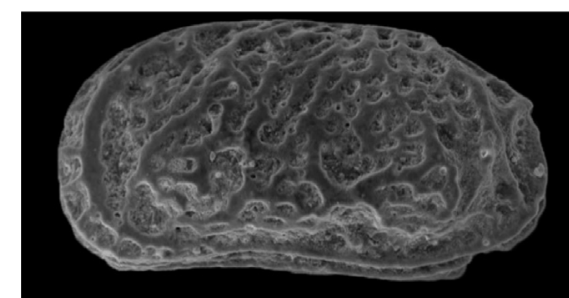

(a)

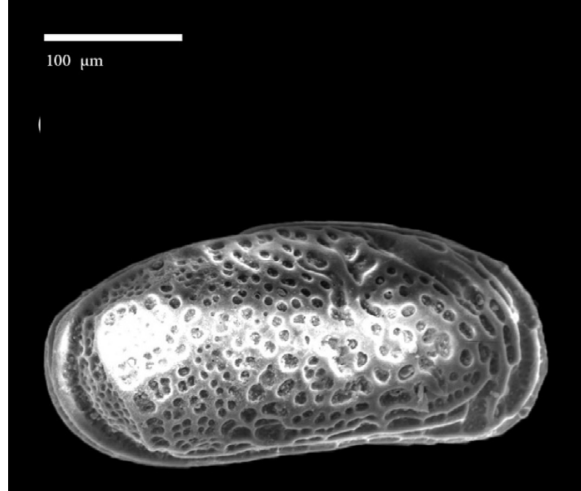

(c)

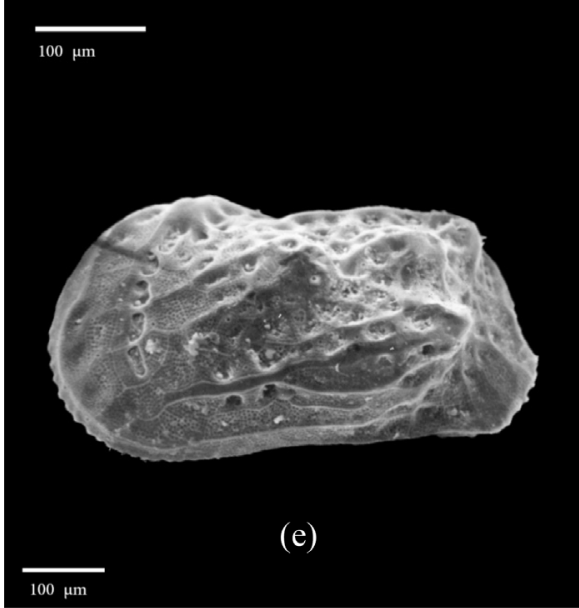

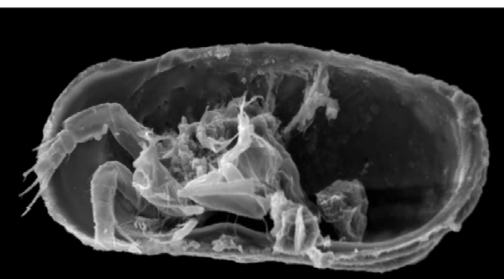

(b) $100 \mu \mathrm{m}$

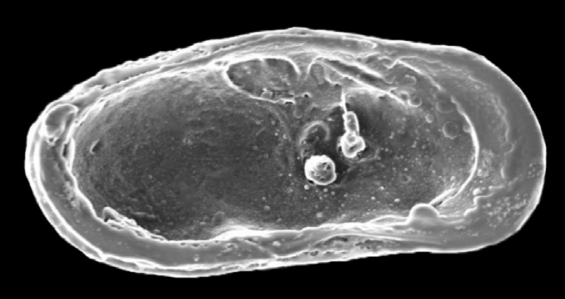

(d)

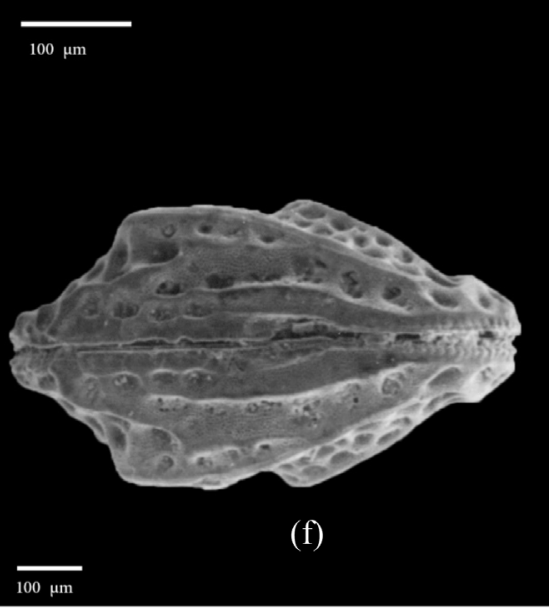

Figure 7. Scanning Electron Microscope showing. (a) External view of carapace of Callistocythere arcana (b) Internal view of right valve of Callistocythere arcana (c) External view of right of Leptocythere arenicola (d) Internal view of left valve of female of Leptocythere arenicola (e) External view of left valve of Quadracythere borchersi (f) Ventral view of carapace of Quadracythere borchersi.

\subsubsection{Quadracythere borchersi (Hartmann, 1964) (Figure 7(e),} Figure 7(f) \& Figure 8(a))

Hemicythere (?) borchersi [1], pls. 56,57,58Figures 318-321, 324-330, 322-323.

Quadracythere borchersi (Hartmann), Bonadouce et al. [2], pl. 5, Figures 5-7.

Quadracythere borchersi (Hartmann). Bonaduce, et al. [23], p. 478.

Quadracythere borchersi (Hartmann), [5], pls.7: 5,6.

Measurements: $\mathrm{L}=0.96 \mathrm{~mm}, \mathrm{H}=0.68 \mathrm{~mm}$.

Geographical distribution: Red Sea.

Occurrence: Quadracythere borchersi present with several numbers in the 
second, fourth and fifth sites (mangrove trees) and occurred in less numbers in the first and third sites (covered with macro-algae).

\section{Ecology:}

Remarks: The species under investigation was described for the first time by [1] as Hemicythere borchersi. Our species have more resembled to Hemicythere borchersi [1] especially in the outlines, carapace ornamentation and in the anterior and posterior tubercles. On the other hand our specimens differ from Quadracythere borchersi in the carapace ornamentations and the shape of posterior margin.

Family: HemicytheridaePuri, 1953

Subfamily: Orionininae Puri, 1953

Genus: Caudites Coryell and Fields, 1937

\subsubsection{Caudites sublevis Hartmann, 1974 (Figure 8(b))}

Caudites cf. C. knysnaensis [56], pls. 60, 150, Figures 449-458, Figure 4.

Caudites sublevis Bonaduce: [48], pl. II, Figure 16.

Caudites sublevis Bonaduce: [54], pl. 2, Figure 6.

Caudites sublevis Bonaduce: [12], Figure 5: 67-70.

Size: L $0.47 \mathrm{~mm}, \mathrm{H} 0.26 \mathrm{~mm}$.

Occurrence: The studied species occurred in less numbers in three sites only.

Geographical distribution: Red Sea, India, Angola, Gulf of Aden.

Remarks: The ventral margin of the present species is more sinuous than that of [12].

Family: Paradoxostomidae

Subfamily: Paradoxostominae

Genus: Paradoxostoma Fischer, 1885.

3.3.19. Paradoxostoma altecaudatum Bonaduce et al., 1980 (Figure 8(c)) Paradoxostoma altecaudatum Bonaduce et al. [27], pI. 10, 12, Figure 1, Figure

2, Figure 5.

Size: $\mathrm{L}=0.75 \mathrm{~mm} ; \mathrm{H}=0.33 \mathrm{~mm}$.

Geographical distribution: Red Sea.

Occurrence: Paradoxostoma altecaudatum occurred in moderate numbers in all collection sites.

Remarks: The valves of Genus Paradoxostoma are thin calcified and nearly smooth. Paradoxostoma altecaudatum is rare in our samples and is smaller than that of Bonaduce et al. [27] and differs from that in the presence of some striated lines on the carapace surface.

Superfamily: Cypridacea Baird, 1845

Family: Paracyprididae Sars, 1923

Genus: Ghardaglaia Hartmann, 1964

\subsubsection{Ghardaglaia triebeli Hartmann, 1964 (Figure 8(d)-(f))}

Ghardaglaia triebeli: [1], pls. 6-9, Figures 23- 40.

Ghardaglaia triebeli Hartmann: Bonaduce et al. [2], pl. 3, Figure 1. 


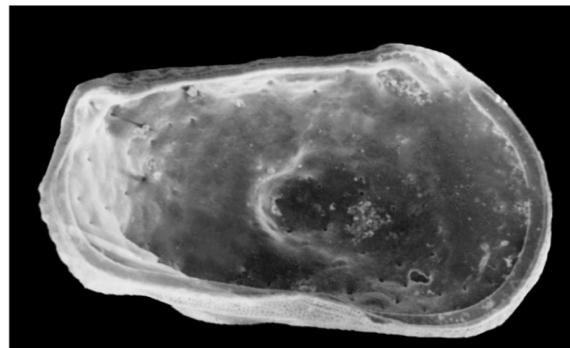

(a)

$100 \mu \mathrm{m}$

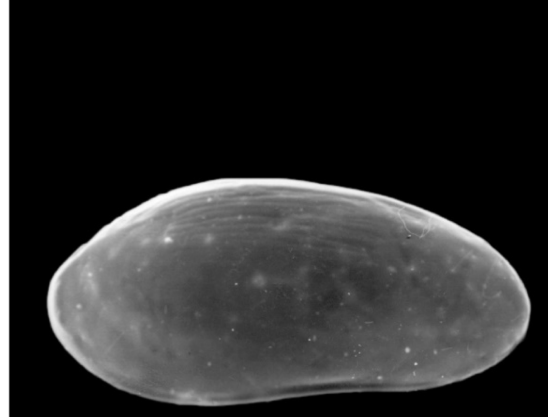

(c)

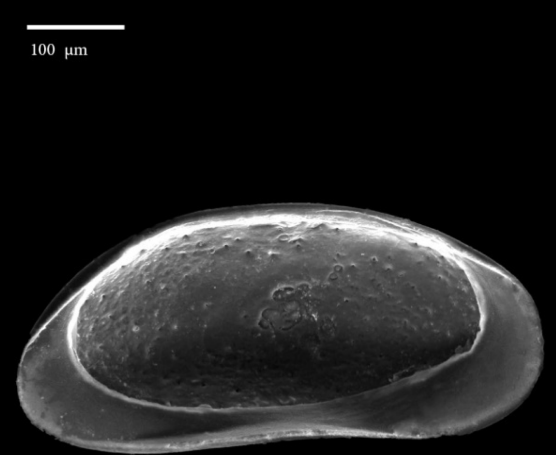

(e)

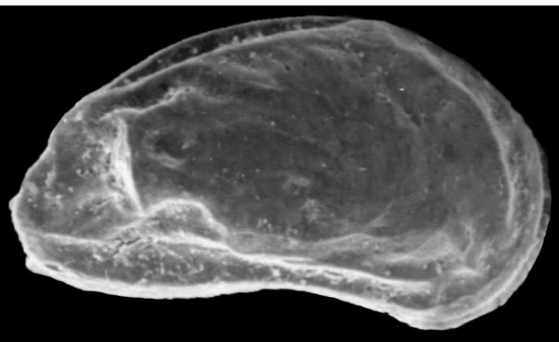

(b)

$100 \mu \mathrm{m}$

(d)

$$
\overline{100 \mu \mathrm{m}}
$$

(f)

$100 \mu \mathrm{m}$

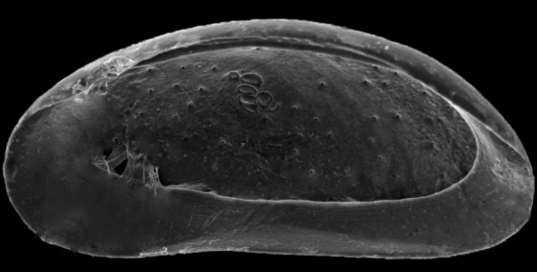

$100 \mu \mathrm{m}$

Figure 8. Scanning Electron Microscope showing. (a) Internal view of left valve of Quadracythere borchersi (b) External view of right valve of Caudites sublevis (c) External view of rightvalve of Paradoxostoma altecaudatum (d) External view of leftt valve of Ghardaglaia triebeli (e) Internal view of left valve of Ghardaglaia triebeli (f) Internal view of right valve of Ghardaglaia triebeli.

Aglaiocypris triebeli (Hartmann): [57], pl. 1, Figure 1w.

Size: L $0.7 \mathrm{~mm}, \mathrm{H} 0.32$.

Geographical Distribution: Red Sea.

Occurrence: Ghardaglaia triebeli is widely distributed species in the Red Sea and occurs with several numbers in the first and third sites.

Ecology: This species found in shallow water and occurred in large numbers in algae. The suitable environmental factors for this species are: Water temperature ranges between $28.8^{\circ} \mathrm{C}-32.6^{\circ} \mathrm{C}, \mathrm{pH}$ varies between 8.27 and 8.48 , salinity 
fluctuates from $42.13 \%$ to $41.22 \%$. Also, dissolved oxygen ranges from 6.9 to $7.2(\mathrm{mg} / \mathrm{l})$.

Remarks: The lateral outlines Aglaiella sp. resembles our species, but the latter has a wider inner lamella. On the other hand, there are no differences between the present species and ones of [1] and Bonadouce et al. [2].

\section{Discussion}

Macro-algae and mangrove trees of the Red Sea are inhabited by different ostracod species. The present study recorded and counted the ostracod species from five collection sites (on the Egyptian Red Sea coast), three sites of them are inhabited by mangrove trees and the other two ones are covered with macro-algae. We concluded that, collection sites occupied by macro-algae have yielded larger numbers and diversity of ostracods than those occupied by mangrove trees. So, the diversity and abundance of ostracod species are controlled by the type vegetation. [5] concluded that the areas with the algae contain dense communities of ostracod species.

Twenty Shallow marine ostracods of five samples from Al-Quseir to Marsa Alam on the Egyptian Red Sea Coast were studied. [4] collected twenty-three ostracod species belonging to 21 genera, and 13 families from Safaga bay along the Red Sea coast, Egypt. Similarly, [5] collected 36 and 26 ostracod species from Wadi Gemal area and Abu Ghoson area, respectively. During our study, the most common species in the collecting region are Loxoconcha ghardaqensis, Xestoleberis rotunda, Paranesidea fracticorallicola, Tanella gracilis and Neonesidea schulzi, whereas, Hemicytherura videns aegyptica and Caudites sublevis occurred in few numbers. [11] reported 83 species belonging to 54 genera from Gulf of Oman at depths ranging from 30 to $103 \mathrm{~m}$. The ostracod species Hemicytherura aegyptica, Tanella gracilis, Moosella striata and Loxoconcha ornatovalve are recorded by [11].

The ostracod species Hiltermannicythere rubrimaris, Loxoconcha ghardaqensis are distributed in the Red Sea, the Gulf of Aden and the East African coast (Al-Abdul-Razzaq et al. [19] [42]; Bonaduce et al. [2], Bonaduce et al. [1] [4] [20] [27] [29] [33] [54]).

Tanella gracilis is common in algae in the area under study. [19] and [37] reported this species from the lagoon in the Arabian Gulf and from the deep water of the Gulf of Oman, respectively. [39] also found T. gracilis in the western coast of India and [38] found it in Indonesia as well as the western coast of Australia.

The recorded fauna show close affinities to those of the Red Sea and the Indo-Pacific region. Also, Tanella gracilis have wide distribution (Red Sea, Gulf of Aden, Kuwait, Gulf of Oman, Arabian Gulf, Australia, west African coast, Kenya, Malaya, Andaman Islands, India, Reunion Islands). Furthermore, Neonesidea schulzi occurred in east Coast of Africa and Neonesidea michaelseni found in Australia and Polynesia. Paranesidea fracticorallicola occurred in Madagascar and Gulf of Oman. Add to that, Moosella striata present in Kenya. Although, most of studied species occurred in red sea and the Indo-pacific region. 
This is due to the dispersal of ostracod species by birds and/or ships.

The present study delivers an initial examination of the taxonomy and distribution of some marine water Ostracoda from the Egyptian western Coast of the Red Sea. Though, further detailed studies are required for a better understanding.

\section{Acknowledgements}

The author wishes to express his sincere gratitude to Professor Munef Mohammed of Department of Earth and Environmental Sciences, Faculty of Science, Sanaa University, for his invaluable advice and continuous encouragement during the course of this work. Our sincere thanks are also due to anonymous reviewers for the improvement of the manuscript.

\section{References}

[1] Hartmann, G. (1964) Zur Kenntnis der Ostracoden des Roten Meeres. Kieler Meeresforsch, 20, 35-127.

[2] Bonaduce, G., Masoli, M. and Pugliese, N. (1976) Ostracoda from the Gulf of Aqaba (Red Sea). Pubblicazioni della Stazione zoological di Napoli, 40, 372-428.

[3] Bonaduce, G., Masoli, M. and Pugliese, N. (1978) Ostracoda from the Gulf of Aqaba (Red Sea). Pubblicazioni della Stazione zoological di Napoli, 40, 372-428.

[4] Helal, S.A. and Abd El-Wahab, M. (2004) Recent Ostracodes from Marine Sediments of Safaga Bay, Red Sea, Egypt. Egypt Journal of Paleontology, 4, 75-93.

[5] Helal, S.A. and Abd El-Wahab, M. (2012) Distribution of Podocopid Ostracods in Mangrove Ecosystems along the Egyptian Red Sea Coast. Crustaceana, 85, 1669-1696. https://doi.org/10.1163/15685403-00003120

[6] Maddocks, R.F. (1969) Revision of Recent Bairdiidae (Ostracoda). Smithsonian Institution Press, Washington DC.

[7] Maddocks, R.F. (1969) Recent Ostracodes of the Family Pontocyprididae Chiefly from the Indian Ocean. Smithsonian Contributions to Zoology, Smithsonian Institution Press, Washington DC, No. 7, 1-56. https://doi.org/10.5479/si.00810282.7

[8] Keij, A.J. (1978) Remarks on the Indo-Pacific Ostracode Genus Loxocochella. Palaeontology, 30, 215-229.

[9] Whatley, R. and Roberts, R. (1995) Marine Ostracoda from Pitcairn, Oeno and Henderson Islands. Biological Journal of the Linnean Society, 56, 359-364. https://doi.org/10.1111/j.1095-8312.1995.tb01096.x

[10] Mostafawi, N. (2003) Recent Ostracods from the Persian Gulf. Senckenbergiana maritima, 32, 51-75. https://doi.org/10.1007/BF03043085

[11] Mostafawi, N., Mohammad, S., Nabavi, B. and Moghaddasi, B. (2010) Ostracods from the Strait of Hormuz and Gulf of Oman, Northern Arabian Sea. Revista Espaola de Micropaleontologa, 42, 243-265.

[12] Mohammed, M. and Keyser, D. (2012) Recent Ostracods from the Tidal Flats of the Coast of Aden City, Yemen. Marine Biodiversity, 42, 247-280. https://doi.org/10.1007/s12526-012-0112-9

[13] Nishath, N.M., Hussain, S.M. and Rajkumar, A. (2015) Distribution of Ostracoda in the Sediments of the North Western Part of the Bay of Angola, India-Implications for Microenvironment. Journal of the Palaeontological Society of India, 60, 27-33. 
[14] Rasheed, D.A. and Ragothaman, V. (1978) Ecology and Distribution of Recent Foraminifera from the Bay of Bengal off Porto Novo. Tamil Nadu State, India. Proceedings of the 7 th Indian Colloquium on Micropalaeontology and Stratigraphy, Madras, December 1978, 263-298.

[15] Benson, R.H. (1961) Ecology of Ostracode Assemblage. In: Moore, R.C., Ed., Treatise on Invertebrate Paleontology, Pt. Q, Arthropoda, Vol. 3, Q56-Q63.

[16] Paterson, M.J. (1993) The Distribution of Microcrustacea in the Littoral Zone of a Freshwater Lake. Hydrobiologia, 263, 173-183. https://doi.org/10.1007/BF00006268

[17] Kiss, A. (2007) Factors Affecting Spatial and Temporal Distribution of Ostracoda Assemblages in Different Macrophyte Habitats of a Shallow Lake (Lake Fehér, Hungary). Hydrobiologia, 585, 89-98. https://doi.org/10.1007/s10750-007-0631-8

[18] Yousef, E.A. (2013) Algal Structural Complexity Effect on Diversity and Abundance of Some Ostracod Species from Red Sea Coast, Egypt. Advances in Life Sciences, 3, 5-17.

[19] Bate, R.H. (1971) The Distribution of Recent Ostracoda in the Abu Dhabi Lagoon, Persian Gulf. In: Oertli, H.J., Ed., Paleoecologie des Ostracodes, Bull Rech Pau-SNPA, Vol. 5, 239-259.

[20] Basha, S.H. (1987) Contribution to the Quaternary Ostracodes of the Jordan Rift Valley. Revista Española de Micropaleontología, 19, 99-110.

[21] Bate, R.H. and Gurney, A. (1981) The Ostracod Genus Loxoconcha Sars from Abu Dhabi Lagoon and Neighbouring Near-Shore Shelf, Persian Gulf. Bulletin of the British Museum (Natural History), 41, 235-251.

[22] Mostafawi, N. (2001) How Severely Was the Persian Gulf Affected by Oil Spills following the 1991 Gulf War. Environmental Geology, 40, 1185-1191. https://doi.org/10.1007/s002540100238

[23] Bonaduce, G., Ciliberto, B., Masoli, M., Minichelli, G. and Pugliese, N. (1983) The Red Sea Benthic Ostracodes and Their Geographical Distribution. Proceedings of the 8th International Symposium on Ostracodes, Houston, 26-29 July 1982, 472-491.

[24] Munef, M.A., Al-Wosabi, M.A., Keyser, D. and Al-Kadasi, W.M. (2012) Distribution and Taxonomy of Shallow Marine Ostracods from Northern Socotra Island (Indian Ocean) Yemen. Revue de micropaleontology, 55, 149-170. https://doi.org/10.1016/j.revmic.2012.06.004

[25] Maddocks, R.F. (1966) Distribution Patters of Living and Subfossil Podocopid Ostracodes in the Nosy Be Area, Northern Madagaskar. University of Kansas Paleontological Contributions, Paper 12, $72 \mathrm{p}$.

[26] Maddocks, R.F. (1995) Mangrove-Mud Ostracoda of Nosy Be, Madagascar. In: Riha, J., Ed., Ostracoda and Biostratigraphy, A. A. Balkema Publishers, Rotterdam, 351-363.

[27] Bonaduce, G., Masoli, M., Minichelli, G. and Pugliese, N. (1980) Some New Species of Ostracoda from the Gulf of Aqaba (Red Sea). Bullettino della Società Paleontologica Italiana, 19, 143-178.

[28] Holden, J.C. (1976) Late Cenozoic Ostracoda from Midway Island Drill Holes. Geological Survey Professional Paper 680 F, 43 p.

[29] Basha, S.H. (1983) Foraminifera and Ostracoda from Holocene Sediments in the Jordanian Part of the Gulf of Aqaba. Dirasat, 5, 109-127.

[30] Titterton, R. and Whatley, R.C. (1988) The Provincial Distribution of Shallow Water Indo-Pacific Marine Ostracoda: Origin, Antiquity, Dispersal Routes and Mechanisms. Developments in Palaeontology and Stratigraphy, 11, 759-786. 
https://doi.org/10.1016/S0920-5446(08)70220-6

[31] Hartmann, G. (1982) Beitrag zur Ostracodenfauna Neuseelands mit einem Nachtrag zur Ostracodenfauna der Westküste Australiens. Mitteilungen aus dem Hamburgischen Zoologischen Museum und Institut, Vol. 79, 119-150.

[32] Hartmann, G. (1984) Zur Kenntnis der Ostracoden der polynesischen Inseln Huahine (Gesellschaftsinseln) und Rangiroa (Tuamotu-Inseln). Mit. Bemerkungen zur Verbreitung und Ausbreitung litoraler Ostracoden und einer Uebersicht ueber die bislang auf den pazifischen Inseln gefundenen Arten. Mitteilungen Hamburgisches Zoologisches Museum und Institut, Vol. 81, 117-169.

[33] Jellinek, T.H. (1993) Zur Ökologie und Systematik rezenter Ostracoden aus dem Bereich des Kenianisschen Barriereriffs. Senckenberg Leth, 73, 83-225.

[34] Hoskin, I.R. (1975) Comparison of Valve Ornamentation in Various Species of Hemicytherura from Western Ireland, the Mediterranean and Red Sea. Revista Española de Micropalaeontology, 7, 91-98.

[35] Gurney, A.R. (1981) On Hemicytherura aegyptica. In: Bate, R.H., Neale, J.W., Shepard, L.M. and Siveter, D.J., Eds., A Stereo-Atlas of Ostracod Shells, Vol. 8, British Micropalaeontological Society, London, 7-12.

[36] Kingma, J.T. (1948) Contributions to the Knowledge of the Toung-Caenozoic Ostracoda from the Malayan Region. Proefscr. Rjks-Univ Utrecht, 119, 3 Abb.

[37] Paik, K.H. (1976) Rezente Ostracoden aus Oberflächensedimenten des Persischen Golfs und des Golfs von Oman. Dissertation, University of Kiel, Kiel.

[38] Hartmann, G. (1978) Die Ostracoden der Ordnung Podocopida G.W. Müller, 1894 der tropisch-subtropischen Westküste Australiens (zwischen Derby im Norden und Perth im Süden). In: Hartmann, G. and Hartmann-Schröder, G., Eds., Zur Kenntnis des Eulitorals der australischen Küsten unter besonderer Berücksichtigung der Polychaeten und Ostracoden, Tl. 1, Mitteilungen Hamburgisches Zoologisches Museum und Institut, Vol. 75, 64-219.

[39] Jain, S.P. (1978) Recent Ostracoda from Mandvi Beach, West Coast of India. Bulletin of the Indian Geologists Association, 11, 89-193.

[40] Hartmann, G. (1980) Die Ostracoden der Ordnung Podocopida G.W. Müller, 1894 der warmtemperierten und subtropisch-tropischen Küstenabschnitte der Süd-und Südostküste Australiens (zwischen Ceduna im Westen und Lake Entrance im Osten). In: Hartmann, G. and Hartmann-Schröder, G., Eds., Zur Kenntnis des Eulitorals der australischen Ksüsten unter besonderer Berücksichtigungdcr Polychaeten und Ostracoden, Tl. 5, Mitteilungen Hamburgisches Zoologisches Museum und Institut, Vol. 77, 111-204.

[41] Hartmann, G. (1981) Die Ostracoden der Ordnung Podocopida G.W. Müller, 1984 der subtropisch-tropischen Ostküste Australiens (zwischen Eden im Süden und Heron-Island im Norden). In: Hartmann, G. and Hartmann Schröder, G., Eds., Zur Kentnnis des Eulitorals derAustralischen Küsten unter besonderer Berücksichtigung der Polychaeten und Ostracoden, Tl. 7, Mitteilungen Hamburgisches Zoologisches Museum und Institut, Vol. 78, 97-149.

[42] Al-Abdul-Razzaq, S.K., Shublaq, S.K. and Al-Sheikh, Z. (1982) Ostracode Distribution and Ecology of Sulaibikhat Bay, Kuwait. Marine Geology, 147, 57-75. https://doi.org/10.1016/0025-3227(82)90019-6

[43] Whatley, R.C. and Zhao, Q. (1988) Recent Ostracoda of the Malacca Straits. Part II. Revista Española de Micropalaeontology, 20, 5-73.

[44] Howe, H.V. and McKenzie, K.G. (1989) Recent Marine Ostracoda (Crustacea) from Darwin and North-Western Australia. Northern Territory Mus Arts Sci Monogr. ser 3,50 . 
[45] Whatley, R.C. and Keeler, N. (1989) Ostracodes actuels de l'île de la Réunion (sudouest de l'Océan Indien). Revista Española de Micropalaeontology, 32, 63-84.

[46] Witte, L.J. (1993) Taxonomy and Origin of Modern West African Shallow Marine Ostracod. Academische Pers B.V, Amsterdam.

[47] Kumar, V. and Hussain, S.M. (1997) A Report on Recent Ostracoda from Pitchavaram Mangroves, Tamilnadu. Geosciences Journal, 18, 131-139.

[48] Hussain, S.M. (1998) Recent Benthic Ostracoda from the Gulf of Mannar, off Tuticorin. Southeast Coast of India. Journal of the Palaeontological Society of India, 43, 1-22.

[49] Hussain, S.M. and Mohan, S.P. (2000) Recent Ostracoda from Adyar River Estuary, Chennai, Tamil Nadu. Journal of the Palaeontological Society of India, 45, 25-31.

[50] Sridhar, S.G.D., Hussain, S.M., Kumar, V. and Periakali, P. (2002) Recent Ostracoda from Palk Bay, off Rameswaram, Southeast Coast.

[51] Arul, B., Sridhar, S.G.D., Hussain, S.M., Darwin Felix, A. and Periakali, P. (2003) Distribution of Recent Benthic Ostracoda from the Sediments of Pitchavaram Mangroves, Tamil Nadu, Southeast Coast of India. Bulletin of Pure \& Applied Sciences, 22F, 55-73.

[52] Hussain, S.M., Krishnamurthy, R., Suresh Gandhi, M., Ilayaraja, K, Ganesan, P. and Mohan, S.P. (2006) Micropalaeontological Investigations on Tsunamigenic Sediments of Andaman Islands. Current Science, 91, 1655-1667.

[53] Gopalakrishna, K., Hussain, S.M., Maheshbilwa, L. and Ayisha, V.A. (2007) Recent Benthic Ostracoda from the Inner-Shelf off the Malabar Coast, Kerala, Southwest Coast of India. Journal of the Palaeontological Society of India, 52, 59-68.

[54] Mohammed, M. (2004) The Study of Ostracoda in Recent Deposits-South West Yemen. PhD Thesis, Baghdad University, Baghdad.

[55] Pugliese, N., Bonaduce, G. and Masoli, M. (1984) Benthic Ostracods from El Hameira (Gulf of Aqabq, Red Sea). Atti Mus Geol Paleont Monfalcone Q. 2, 1-22.

[56] Hartmann, G. (1974) Die Ostracoden des Untersuchungesgebiets. In: Hartmann-Schröder, G. and Hartmann, G., Eds., Zur Kenntnis des Eulitorals der Afrikanischen Westküste zwischen Angola und Kap der Guten Hoffnung und der Afrikanischen Ostküste von Südafrika und Mocambique unter besonderer Berücksichtigung der Polychaeten und Ostracoden, Tl. 3, Mitteilungen Hamburgisches Zoologisches Museum und Institut, Erg. Bd, Vol. 69, 229-520.

[57] Bate, R.H. (1970) The Distribution of Recent Ostracoda in the Abu Dhabi Lagoon, Persian Gulf. In: Oertli, H.J., Ed., Paleoecologic ostracodes Pau 1970, Bull. Centre Rech. Pau-SNPA, 5 suppl., 239-256. 